Research Report

\title{
Dental and Oral Health Empowerment Program for Elderly using BULAN KESGILUT Book
}

\author{
Alvita Wibowo, Rima Arsyilviasari, Tiara Meilena, Ayu Setyowati, Retta Gabriella, Nur Latifah and R. \\ Darmawan Setijanto \\ Departement Dental Public Health, \\ Faculty of Dental Medicine, Universitas Airlangga \\ Surabaya - Indonesia
}

\begin{abstract}
Background: Dental and oral health problems occur in all age groups, including the elderly. Dental caries is one of the dental and oral health problems. An epidemiological study reported that $83.5 \%$ out of 91 elderly respondents did not have a routine dental check-up. The data concluded that those who routinely have dental check-up had a lower caries risk than the others. The public health centre did not have data about the total of elderly visitors in the dental poly unit. The BULAN KESGILUT book aimed to help to monitor dental and oral health status in the elderly. Purpose: To help the dental poly and elderly visitors to have medical records related to dental and oral health using BULAN KESGILUT book. Methods: The program adopted an indirect health education method involving cadres and dentists from the public health centre. The counselling was done by group. The lecture consisted of dental and oral health material printed in the BULAN KESGILUT book. We have then informed the dentists on how to record the dental and oral health status in the BULAN KESGILUT book and educate the cadres on how to read those records. Results: The mean of cadres' understanding of BULAN KESGILUT book was 97.92\%, and the mean of cadres' information dissemination related to BULAN KESGILUT book was 55.81\%. Conclusion: The program results showed that BULAN KESGILUT was an effective media in monitoring dental and oral health status in the elderly. However, a continuous promotion by the cadres and the public health center is necessary.
\end{abstract}

Keywords: Elderly; dental health education; empowerment; medical records

Correspondence: R Darmawan Setijanto, Department of Dental Public Health, Faculty of Dental Medicine, Universitas Airlangga, Jl. Prof. Dr. Moestopo 47 Surabaya 60132 - Indonesia. E-mail: r-darmawan-s@fkg.unair.ac.id

\section{INTRODUCTION}

Dental and oral health problems occur in all age groups, including the elderly. Dental caries is one of the dental and oral health problems. A preliminary epidemiological study reported that $83.5 \%$ of 91 elderly respondents did not have a routine dental check-up. Cross-tabulation of DMF index and dental check-up frequency showed that the elderly who did not have routine 6-month dental check-up were 1.39 times more likely to have DMF index of $>13 \leq 6$ months). Also, elderly who did not have routine 6-month dental check-up were 1.18 times more likely to have $\mathrm{D}$ index of $>3$. The data concluded that those who routinely have dental check-up had a lower caries risk than the others.

An interview with a dentist revolved that Jagir Public Health Centre has been proactively promoting dental health check-ups for the elderly in the local Integrated Health Centre for Elderly (POSLA). The public health centre did not have data about the total of elderly visitors in the dental poly unit. The empowerment program was dental and oral health monitoring using BULAN KESGILUT book. The book consisted of information about toothbrushing for full/partial edentulous person, how to maintain dentures hygiene, how to make herbal mouthwash, dental and oral health status card, odontogram, and quality of life score.

Community empowerment is a process to increase the community's capacity to utilize the resources, both human resources (HR) and natural resources (NR), for their welfare. ${ }^{1}$ The process should also promote a more independent community and motivate the community to participate in the empowerment program. ${ }^{2}$ In this case, the community serves the actor or centre of the empowerment process.,

The program adopted a direct health education method using lecture session to the cadres and the dentists. The counselling was done by group. The lecture consisted of 
Indonesian Journal of Dental Medicine Volume 3 Issue 1 2020; 1-3

dental and oral health material printed in the BULAN KESGILUT book. We have then informed the dentists on how to record the dental and oral health status in the BULAN KESGILUT book and educate the cadres on how to read those records.

The health promotion media was BULAN KESGILUT book. The book consisted of information about toothbrushing for full/partial edentulous person, how to maintain dentures hygiene, how to make herbal mouthwash, dental and oral health status card, odontogram, and quality of life score.

\section{MATERIALS AND METHODS}

The program was evaluated using qualitative approach with interview techniques. The first interview was about BULAN KESGILUT book understanding of the cadres. The second interview allowed the cadres to reexplain the information to the instructor. This was to examine cadres' communication skill in disseminating information to the elderly. The next examination was carried out in the POSLA. We examined the strategies of the cadres in disseminating information to the elderly. The score list consisted of 8 items, each representing the aspects of cadres' understandings.

Table 1. Knowledge and understanding of cadres

\begin{tabular}{|l|c|c|c|}
\hline $\begin{array}{l}\text { Name of } \\
\text { Cadre }\end{array}$ & POSLA & Achievement & Target \\
\hline $\begin{array}{l}\text { Wartinah } \\
\text { Wahyudi }\end{array}$ & $\begin{array}{c}\text { Pelangi Nu- } \\
\text { santara }\end{array}$ & $100 \%$ & $100 \%$ \\
\hline Yanti & Sawunggaling & $100 \%$ & $100 \%$ \\
\hline $\begin{array}{l}\text { Surya } \\
\text { Wijaya }\end{array}$ & Sari Asih & $100 \%$ & $100 \%$ \\
\hline Mulyani & Pramoda Loka & $100 \%$ & $100 \%$ \\
\hline Soehartati & Pramoda Loka & $100 \%$ & $100 \%$ \\
\hline Sumariyati & Kartika & $100 \%$ & $100 \%$ \\
\hline Siti Rahaju & Kartika & $100 \%$ & $100 \%$ \\
\hline Sulis A. & Mentari & $100 \%$ & $75 \%$ \\
\hline Soetjipto & Mentari & $100 \%$ & $100 \%$ \\
\hline Heriyanto & Pertiwi & $100 \%$ & $100 \%$ \\
\hline Sudarwati & Adi Darma & $100 \%$ & $100 \%$ \\
\hline Mita & Adi Darma & $100 \%$ & $100 \%$ \\
\hline Mean & $100 \%$ & $97.92 \%$ \\
\hline
\end{tabular}

https://e-journal.unair.ac.id/IJDM

\section{RESULTS}

The BULAN KESGILUT book empowerment program involved 12 cadres from 8 POSLA (Table 1). The cadres' understanding of the BULAN KESGILUT book empowerment program. 11 out of 12 cadres got $100 \%$ score in understanding BULAN KESGILUT book empowerment program and 1 remaining cadre got $75 \%$ score.

The cadres' information dissemination strategies of BULAN KESGILUT book empowerment program can be seen in Table 2. The information dissemination score of cadres of Sari Asih Posyandu was $60 \%$, cadres of Pramoda Loka Posyandu was 64\%, cadres of Mentari Posyandu was $51.43 \%$, and cadres of Pertiwi Posyandu was $44 \%$.

\section{DISCUSSION}

The success percentage of BULAN KESGILUT book health promotion was high. This was reflected by cadres' knowledge and understanding of the program. The empowerment program consisted of a lecture session, allowing the speaker and the cadres to interact and engage. ${ }^{5}$ The speaker has delivered the information clearly. The cadres suggested that the ondontogram include the status of filled tooth as well. The dentist also suggested changing the odontogram from labial view to occlusal view for a better understanding of the dental and oral health status. The cadres also suggested that the elderly should receive a copy of their dental and oral health status for self-monitoring and making them aware of their dental and oral health status.

Health promotion strategies for the elderly generally have three basic aims as follows: maintaining and increasing functional capacity, ${ }^{6}$ maintaining or improving self-care, ${ }^{7}$ and stimulating one's social network. ${ }^{8,9}$ The idea behind these strategies is to contribute to a longer, independent, and self-sufficient quality of life. ${ }^{10,11}$ It should be noticed that there is an additional objective to be considered: the significance of social participation and integration of the elderly to maintain the quality of life at old age. ${ }^{5,12}$

The information dissemination strategies implemented by the cadres had a low percentage. Many elderlies failed

Table 2. Information dissemination strategies of cadres about BULAN KESGILUT book

\begin{tabular}{|c|c|c|c|}
\hline $\begin{array}{l}\text { Name of } \\
\text { Health } \\
\text { Cadre }\end{array}$ & POSLA & Targets & Achievement \\
\hline $\begin{array}{l}\text { Surya } \\
\text { Wijaya } \\
\end{array}$ & Sari Asih & $100 \%$ & $60 \%$ \\
\hline Mulyani & Pramoda Loka & $100 \%$ & $64 \%$ \\
\hline Soehartati & Pramoda Loka & $100 \%$ & $64 \%$ \\
\hline Sulis A. & Mentari & $100 \%$ & 51.43 \\
\hline Soetjipto & Mentari & $100 \%$ & 51.43 \\
\hline Herryanto & Pertiwi & $100 \%$ & $44 \%$ \\
\hline \multicolumn{2}{|c|}{ Mean } & $100 \%$ & $55.81 \%$ \\
\hline
\end{tabular}


Indonesian Journal of Dental Medicine Volume 3 Issue 1 2020; 1-3

to understand how to read the odontogram and quality of life scores because the cadres missed this section. The presentation of cadres about dental and oral health in elderly was also not engaging that it bored some elderly. Therefore, it is important to not only pay attention to understanding the information but also practicing an engaging presentation. Some elderly looked tired because they had morning exercise before attending the empowerment program.

The BULAN KESGILUT book empowerment program was designed innovatively, covering information about toothbrushing for full/partial edentulous person, how to maintain dentures hygiene, how to make herbal mouthwash, dental, and oral health status card, odontogram, and quality of life score. The BULAN KESGILUT book has allowed the elderly to self-monitor their dental and oral health status. The elderly can also find out his/her quality of life inside the BULAN KESGILUT book.

The weaknesses of this program were that the elderly struggled to read that they needed someone else to read the information. The program required a continuous promotion to make use of BULAN KESGILUT book.

The opportunity of this program was that BULAN KESGILUT book encouraged the elderly to have routine dental and oral health check-up. The elderly can take care of their dental and oral health according to the guidelines in the BULAN KESGILUT book.

The threat of this program was that BULAN KESGILUT book might be lost. Elderly with difficulty in reading eventually become uninterested in the program.

\section{CONCLUSION}

BULAN KESGILUT book is an effective media for the elderly in self-monitoring their dental and oral health status.
However, a continuous program was needed to make use of the book.

\section{REFERENCES}

1. Ambar ST. Kemitraan dan Model-Model Pemberdayaan. Yogyakarta: Graha Ilmu Kartasasmita; 2004. 215 p.

2. Budiharto. Pengantar Ilmu Perilaku Kesehatan dan Pendidikan Kesehatan Gigi. Jakarta: EGC; 2009. 110 p.

3. Slamet Y. Pembangunan Masyarakat Berwawasan Partisipasi. Surakarta: Sebelas Maret University Press, 1993; 2004. $187 \mathrm{p}$.

4. Kementrian Kesehatan Republik Indonesia. Buku Panduan Pelatihan Kader Kesehatan Gigi dan Mulut di Masyarakat. Jakarta: Kementrian Kesehatan Republik Indonesia; 2012.

5. Palupi R, Berniyanti T, Bramantoro T, Sosiawan A, Wening GS, Kusumo A. Oral health related systemic disease education for elderly age group. J Int Oral Heal. 2019 Jan $1 ; 11(7): 30$.

6. Bramantoro T, Berniyati T, Wening GS, Sosiawan A, Palupi R, Zamzam A. Self-made herbal mouthwash training in elderly community as an empowerment program for improving oral hygiene. J Int Oral Heal. 2019 Jan 1;11(7):37.

7. Heavey E, Baxter K, Birks Y. LONG-TERM CARE. 2019;

8. Lindström B. Workshop salutogenesis and the future of health promotion and public health. Scand J Public Health. 2018 Feb 1;46(20 suppl):94-8.

9. Gunawan S. Mewujudkan Kesejahteraan Bangsa: Menanggulangi Kemiskinan dengan Prinsip Pemberdayaan Masyarakat. Jakarta: Elex Media Komputindo; 2009. 141 p.

10. World Health Organization. World Report on Ageing and Health. WHO. 2015.

11. Ermawati T, Sari DS. Upaya Peningkatan Kesehatan Gigi Dan Mulut Pada Lansia (Improving the Oral Health of Erderly). 2014;

12. Seeman TE. Social ties and health: The benefits of social integration. Ann Epidemiol. 1996 Sep;6(5):442-51. 